\title{
Non-overlap of hosts used by three congeneric and sympatric loranthaceous mistletoe species in an Amazonian savanna: host generalization to extreme specialization
}

\author{
Rodrigo Ferreira Fadini ${ }^{1,2}$
}

Recebido em 1/10/2010. Aceito em 27/03/2011

\begin{abstract}
RESUMO
(Não-sobreposição de hospedeiros utilizados por três espécies de ervas-de-passarinho lorantáceas congêneres e simpátricas em uma savana Amazônica: generalização pelo hospedeiro à extrema especialização). Duas hipóteses principais predominam na literatura sobre a especificidade entre ervas-de-passarinho e hospedeiros: (1) ervas-de-passarinho só poderão se especializar em espécies de plantas em que elas são frequentemente depositadas; e (2) compatibilidade entre as ervas-depassarinho e as espécies de plantas é um prerequisito para o parasitismo. Explorei estas hipóteses com o estudo dos padrões de deposição de sementes e a compatibilidade entre ervas-de-passarinho e hospedeiros em populações de três espécies de ervas-de-passarinho congenéricas e simpátricas do gênero Psittacanthus (P. biternatus, P. eucalyptifolius and P. plagiophyllus - Loranthaceae) e registrei a presença ou ausência destas três espécies em 15 espécies de árvores em uma mancha de savana na Amazônia. Entre as cinco espécies de árvores que eu encontrei infectadas, também registrei se elas possuíam pelo menos uma semente de erva-de-passarinho de qualquer das espécies aderida aos seus galhos. Finalmente, plantei sementes de todas as espécies de ervas-de-passarinho nas mesmas árvores em várias espécies de hospedeiros e não-hospedeiros e registrei a sobrevivência das sementes e o estabelecimento ao final de 7 (P. plagiophyllus) e 12 meses (P. biternatus e P. eucalyptifolius). Não houve sobreposição entre as árvores utilizadas como hospedeiros pelas três espécies de Psittacanthus. As espécies de ervas-de-passarinho mais especializadas ocorreram em diferentes espécies de hospedeiros com baixa abundância relativa na área de estudo (Psittacanthus eucalyptifolius em Vatairea macrocarpa (Benth.) Ducke, e P. plagiophyllus em Anacardium occidentale L.). A compatibilidade entre a erva-de-passarinho e o hospedeiro, e não o padrão de deposição de sementes, foi o fator mais propício a explicar os padrões de uso de hospedeiros por Psittacanthus neste local.
\end{abstract}

Palavras-chave: especificidade por hospedeiro; Loranthaceae; Psittacanthus; hipótese da fragmentação de recurso; germinação de sementes; estabelecimento de plântula

\begin{abstract}
(Non-overlap of hosts used by three congeneric and sympatric loranthaceous mistletoe species in an Amazonian savanna: host generalization to extreme specialization). Two main hypotheses predominate in the literature on mistletoe-host specificity: (1) mistletoes are only likely to specialize on plant species on which they are frequently deposited; and (2) compatibility between mistletoes and plant species is a prerequisite for mistletoe-host parasitism. I explored these hypotheses by studying the seed deposition patterns and mistletoe-host compatibility in populations of three congeneric and sympatric mistletoe species of the genus Psittacanthus (P. biternatus, P. eucalyptifolius and P. plagiophyllus - Loranthaceae). I recorded the presence or absence of these mistletoe species in 15 tree species in a savanna patch in Amazonia. Among the five tree species that I found to be potential hosts (at least one tree individual infected), I also recorded if they had at least one mistletoe seed of any species attached to their branches. Finally, I planted seeds of all mistletoe species on the same individual trees in various hosts and non-host species and recorded seed survivorship and seedling establishment within 7 (P. plagiophyllus) to 12 months (P. biternatus and $P$. eucalyptifolius) after planting. There was no overlap among trees used as hosts by the three Psittacanthus species. The most specialized mistletoe species occurred in different host tree species with low relative abundance at the study site (Psittacanthus eucalyptifolius on Vatairea macrocarpa (Benth.) Ducke, and P. plagiophyllus on Anacardium occidentale L.). Mistletoe-host compatibility, and not seed deposition patterns, was the factor most likely to explain patterns of host use by Psittacanthus species at this study site.
\end{abstract}

Key words: host specificity; Loranthaceae; Psittacanthus; resource-fragmentation hypothesis; seed germination; seedling establishment

Instituto Nacional de Pesquisas da Amazônia, Programa de Pós-Graduação em Ecologia, Manaus, AM, Brazil

2 Universidade Federal do Oeste do Pará, Instituto de Biodiversidade e Florestas, Santarém, PA, Brazil - Author for correspondence: rfadini@gmail.com 


\section{Introduction}

Mistletoes are plants that locally parasitize only a subset of potential hosts and, like other parasites, they frequently show specificity for the most common host trees (Norton \& Carpenter 1998, and references therein). This pattern is mostly found in less diverse forests such as in the Eucalyptus forests of Australia (Barlow \& Wiens 1977), and in the Nothofagus forests of New Zealand (Norton \& De Lange 1999), but also occurs in more diverse savannas (Arruda et al. 2006).

Although high specialization in some mistletoe species may be only the result of frequent encounters between mistletoe seeds and the commonest plants, a few other studies have argued that non-random perch preferences of seed dispersers are also important for shaping the patterns of mistletoe infection prevalence (proportion of infected) and, ultimately, determining host specificity (Monteiro et al. 1992). The decisions taken by birds may either result in a pattern that concentrates mistletoe seeds on the most abundant trees (López De Buen \& Ornelas 1999), or even on the less abundant ones (Aukema \& Martinez Del Rio 2002; Roxburgh \& Nicolson 2005).

A different perspective is offered in studies that focus on the processes of mistletoe-host compatibility (May 1971; Yan \& Reid 1995). Mistletoe-host compatibility is a result of the genetically and, perhaps, environmentally determined biochemical, mechanical, and physiological processes in the parasite and host, including mistletoe infectivity (such as the production of enzymes) and host susceptibility (such as bark and xylem resistance) (Yan 1993). Mistletoe-host compatibility is a trait that may counteract or amplify the effects of seed rain on the observed distribution of mistletoes.

Few studies have disentangled the roles of tree species abundance, seed dispersal, and mistletoe-host compatibility in determining the patterns of mistletoe infection prevalence among different tree species, and among different mistletoe species (e.g. Yan 1993; Roxburgh \& Nicolson 2005). In this study, I set out to distinguish the hosts from non-host trees of three congeneric mistletoe species (Psittacanthus biternatus, P. eucalyptifolius and P. plagiophyllus - Loranthaceae) while controlling for patterns of seed rain. I investigated three of the potential processes that determine the observed association between mistletoes and tree species: seed deposition, seed survivorship and seedling establishment. My main questions were: (i) Do mistletoes overlap the tree species used as hosts? (ii) What are the roles of seed deposition and mistletoe-host compatibility in determining associations between mistletoes and tree species? I predicted that (1) mistletoe species would specialize on the most common trees; further, I predicted that (2) mistletoes would infect the closely related trees. I explored these predictions by surveying for mistletoe infections on various species of trees and by conducting a seed inoculation experiment on various potential host trees.

\section{Material and methods}

\section{Study site and species}

This study was conducted in a patch of Amazonian savanna (a Cerrado like vegetation, $1 \mathrm{~km} \mathrm{x} 1 \mathrm{~km}$ ) on the right margin of the Tapajós River, near Alter do Chão village, Santarém, Pará, Brazil (S 2 31', W 5900'). The study site is unburned for the last 10 years (Albertina Lima, pers. comm.). Because of this, it was chosen for the present study. There are large clumps of fire sensitive shrubs and at least 22 tree species typical of South American savannas such as Byrsonima spp. (Malpighiaceae), Salvertia convallariodora and Qualea grandiflora (Vochysiaceae), Lafoensia pacari (Lythraceae) and Pouteria ramiflora (Sapotaceae), some of the most abundant species (Sanaiotti \& Magnusson 1995). Canopy is discontinuous, and average tree height is only $3.17 \mathrm{~m}$ (Miranda 1993). Most of the rainfall is between December and April. Mean annual rainfall is $2192 \mathrm{~mm}$, and mean annual temperature is $27.5^{\circ} \mathrm{C}$.

The three mistletoe species studied were: Psittacanthus biternatus (Hoffmanns.) G. Don, P. eucalyptifolius (Kunth) G. Don and P. plagiophyllus Eichler. Species are woody, aerial hemiparasitic shrubs, possessing a single, large haustorium deeply attached to their host's branches, which provides them with water, minerals, and some nutrients (Marshall \& Ehleringer 1990). Mature fruits are black pseudo-berries, and the single seeds are mostly dispersed by tyrant flycatchers through regurgitation. For instance, at least $P$. plagiophyllus is mainly dispersed by the small flycatcher Elaenia cristata (Fadini et al. 2009). All mistletoe seeds are easily distinguishable from each other because they have different numbers, shape, size and aspect of their cotyledons.

\section{Mistletoe infection and seed deposition patterns}

From middle August to November 2006, I quantified the general pattern of parasitism in trees located on 16 sample plots randomly selected within the study site (dataset 1 ). Plots were at least $50 \mathrm{~m}$ apart, and all trees $\geq 2 \mathrm{~m}$ tall were counted in a circle of $10 \mathrm{~m}$ radius. For each tree I recorded: species, height, DSH (diameter at soil height), presence/ absence of mistletoe infections, and mistletoe species, if present. To increase the sample size, I also used a second dataset (dataset 2) in which I searched actively for all host trees infected by at least one of the three mistletoe species found in dataset 1 in a 4.5 ha plot $(150 \mathrm{~m} \times 300 \mathrm{~m})$. In this second dataset, I also recorded the presence of mistletoe seeds on branches as well as the number of mistletoe infections on the host trees. Furthermore, to minimize the potential effects of false-absences (sensu Martin et al. 2005), two observers performed the sampling simultaneously. I searched for mistletoes from the ground using binoculars when the tree was large (ca. 5 to $6 \mathrm{~m}$ ), while the second observer climbed the tree using an aluminum ladder. I only considered the 
hosts actually infected by each one of the mistletoe species to calculate mistletoe infection prevalence. In comparisons involving dataset 2, I considered these five tree species as potential hosts for the analyses of seed rain.

\section{Seed survivorship and seedling establishment}

From the end of March to mid May 2007, individuals of nine experimental tree species were inoculated simultaneously with seeds of $P$. biternatus and P. eucalyptifolius, and in September 2008 with seeds of P. plagiophyllus (Tab. 1). I chose two groups of experimental tree species, those I previously knew to be infected by at least one mistletoe species (for which I slightly increased sample size), and those with high relative abundance in the study site but without previous information on parasitism (6 to 10 individuals per tree species, mean $=7.1 \pm 1.4)($ Tab. 1$)$. Experimental trees were not parasitized, were at least 2 $\mathrm{m}$ tall, and appeared healthy at the beginning of the experiment. Individuals were geo-referenced, marked with aluminum tags, and located at least $50 \mathrm{~m}$ from each other. On each tree, three branches were tagged with sequential numbers and measured (precision $=0.1 \mathrm{~mm}$ ) to receive the respective mistletoe seeds.

Fruits were collected from mistletoes on different trees located at least $50 \mathrm{~m}$ from the $150 \times 300 \mathrm{~m}$ plot, and placed in separated paper bags to inoculate the seeds one day later. I removed the pericarp of five fruits per species by hand and arranged seeds linearly $2 \mathrm{~cm}$ apart on the tagged horizontal branches (one branch for each species). Mistletoe species were inoculated on each branch at random, using numbered papers to sort a number from 1 to 3 . I inoculated seeds of P. biternatus and P. eucalyptifolius in two of them. I returned 18 months later (September 2008) to conduct the same experiment with $P$. plagiophyllus on the remaining branch. Each day, mistletoe seeds were inoculated on all tree species simultaneously, usually one or two individuals per tree species per day. If seeds ended, a new batch was collected and inoculated in the next day. The proportion of established seedlings (presenting primordial leaves) and seeds that stayed alive (established seedlings + germinated seeds) were counted in the $12^{\text {th }}$ month for P. biternatus and P. eucalyptifolius, and in the $7^{\text {th }}$ month for P. plagiophyllus. All results are presented with their means \pm SE.

\section{Statistical analyses}

I used chi-square to compare the expected and the observed frequencies of seeds arriving at different host trees for each mistletoe species. The expected frequency was based on the relative abundance of each host in the large plot (dataset 2). I used ANOVA to test for differences in seed survival and seedling establishment. Finally, I used correlation tests to compare seed deposition, seed survival and seedling establishment among mistletoes whenever possible.

\section{Results}

I recorded 15 tree species in dataset 1 . However, only four presented mistletoe infections. Among them, there was no overlap of hosts used by the three mistletoe species. I tagged 4102 tree individuals in dataset 2 and confirmed the non-overlap. Finally, I showed that $17 \%$ of all experimentally inoculated mistletoe seeds survived and only $5.8 \%$ established in the seed inoculation experiment; all were only able to germinate and establish on the same trees found as hosts in datasets 1 and 2.

\section{Intraspecific patterns of host use, seed deposition, seed survivorship and seedling establishment}

\section{Psittacanthus biternatus}

This species infected mainly the commonest tree species in the dataset 1 (Byrsonima crassifolia, 23\% of 553 individuals), its congeneric (B. coccolobifolia, 5.2\%), and Pouteria ramiflora (8.5\%) (Tab. 2). In dataset 2 , among the five potential host trees, Byrsonima crassifolia was also the most abundant, $P$. ramiflora the third and B. coccolobifolia the fourth (Tab. 3). Patterns of infection by P. biternatus in dataset 2 was inversely proportional to host abundance, thus B. crassifolia was the most abundant host species but had the lowest mistletoe infection prevalence, followed by $P$. ramiflora and B. coccolobifolia (Tab. 3). Byrsonima coccolobifolia and $P$. ramiflora had many more infected individuals than expected from their relative abundance $\left(x^{2}=6.64, \mathrm{df}=2, \mathrm{P}\right.$ $<0.05$ ), while $B$. crassifolia was less infected than expected.

Seeds of $P$. biternatus were found in only 13 trees $(0.3 \%$ of the tagged trees) and arrived at $0.4 \%$ of its potential host trees in dataset 1 (sum of B. crassifolia, B. coccolobifolia and $P$. ramiflora individuals). It was unfruitful to analyze the seed-rain data for P. biternatus due to the low expected frequencies of trees receiving its seeds (Fig. 1a). Seeds inoculated experimentally germinate (open cotyledons) within a few hours after being released from the pericarp. Survivorship of seeds of $P$. biternatus was widespread, but markedly different among the nine potential host trees (Fig. 1b). Seedling establishment, on the other hand, was limited to three species: Byrsonima coccolobifolia, B. crassifolia and Pouteria ramiflora (Fig. 1c). 6.3\% of inoculated seeds established in the first year. The total percentage of established seedlings was $32 \%$ in B. coccolobifolia, $2 \%$ in B. crassifolia and $10 \%$ in $P$. ramiflora.

\section{Psittacanthus eucalyptifolius}

Any of the tree species sampled was parasitized by $P$. eucalyptifolius in dataset 1 (Tab. 2). However, it was found parasitizing Vatairea macrocarpa outside the sample plots, and therefore, I included this species as a potential host tree for P. eucalyptifolius in dataset 2 (Tab. 3). Seeds of P. euca- 
Table 1. Number of individuals of nine tree species in which seeds of Psittacanthus spp. were experimentally inoculated in Alter do Chão, Pará, Brazil. The last line shows the total number of seeds inoculated on these trees for each mistletoe species.

\begin{tabular}{lccc}
\hline \multirow{2}{*}{ Host species } & \multicolumn{2}{c}{ Mistletoe species } \\
\cline { 2 - 4 } Anacardium occidentale & P. biternatus & P. eucalyptifolius & P. plagiophyllus \\
Byrsonima coccolobifolia & 6 & 6 & 6 \\
Byrsonima crassifolia & 10 & 8 & 6 \\
Hymatanthus Fallax & 10 & 7 & 6 \\
Lafoensia pacari & 7 & 7 & 6 \\
Pouteria ramiflora & 7 & 7 & 6 \\
Qualea grandiflora & 10 & 8 & 6 \\
Salvertia convallariodora & 7 & 7 & 6 \\
Vatairea macrocarpa & 7 & 7 & 6 \\
\hline Total number of seeds inoculatedà & 7 & 10 & 270 \\
\hline
\end{tabular}

Table 2. Tree abundance and prevalence of three mistletoe species of Psittacanthus (Loranthaceae) in 16 circular plots of savanna near Alter do Chão, Pará, Brazil (data from dataset 1 ). Host trees with at least one infected individual are in bold.

\begin{tabular}{|c|c|c|c|c|c|c|c|}
\hline \multirow[t]{2}{*}{ Tree species } & \multirow[t]{2}{*}{ Family } & \multirow{2}{*}{$\begin{array}{c}\text { Total } \\
\text { abundance }\end{array}$} & \multirow{2}{*}{$\begin{array}{l}\text { Average abundance } \\
\text { per plot }( \pm \mathrm{SD})\end{array}$} & \multirow[t]{2}{*}{ No. of plots } & \multirow{2}{*}{$\begin{array}{c}\begin{array}{c}\text { Psittacanthus } \\
\text { biternatus }\end{array} \\
\text { Prevalence (\%) }\end{array}$} & \multirow{2}{*}{$\begin{array}{c}\begin{array}{c}\text { Psittacanthus } \\
\text { eucalyptifolius }\end{array} \\
\text { Prevalence (\%) }\end{array}$} & \multirow{2}{*}{$\begin{array}{c}\begin{array}{c}\text { Psittacanthus } \\
\text { plagiophyllus }\end{array} \\
\text { Prevalence (\%) }\end{array}$} \\
\hline & & & & & & & \\
\hline Anacardium occidentale ${ }^{\star}$ & Anacardiaceae & 6 & $0.38 \pm 0.7$ & 4 & - & - & $3(50)$ \\
\hline Xylopia aromatica & Annonaceae & 33 & $2.06 \pm 2.3$ & 12 & - & - & - \\
\hline Hymatanthus Fallax* & Apocynaceae & 43 & $2.7 \pm 2.3$ & 14 & - & - & - \\
\hline Tabebuia ochracea & Bignoniaceae & 6 & $0.38 \pm 0.7$ & 4 & - & - & - \\
\hline Bowdichia virgilioides & Fabaceae & 10 & $0.63 \pm 0.8$ & 7 & - & - & - \\
\hline Vatairea macrocarpa ${ }^{*}$ & Fabaceae & 47 & $2.94 \pm 2.1$ & 14 & - & - & - \\
\hline Sclerolobium paniculatum & Fabaceae & 27 & $1.7 \pm 3.1$ & 8 & - & - & - \\
\hline Lafoensia pacari* & Lythraceae & 35 & $2.2 \pm 1.4$ & 15 & - & - & - \\
\hline Byrsonima coccolobifolia ${ }^{*}$ & Malpighiaceae & 29 & $1.8 \pm 1.3$ & 13 & $3(10)$ & - & - \\
\hline Byrsonima crassifolia ${ }^{*}$ & Malpighiaceae & 127 & $7.9 \pm 5.8$ & 16 & $1(0.8)$ & - & - \\
\hline Roupala montana & Proteaceae & 3 & $0.2 \pm 0.8$ & 1 & - & - & - \\
\hline Pouteria ramiflora ${ }^{*}$ & Sapotaceae & 47 & $2.9 \pm 3.5$ & 13 & $1(2)$ & - & - \\
\hline Simarouba amara & Simaroubaceae & 8 & $0.5 \pm 0.9$ & 5 & - & - & - \\
\hline Qualea grandiflora ${ }^{*}$ & Vochysiaceae & 62 & $3.9 \pm 2.4$ & 16 & - & - & - \\
\hline Salvertia convallariodora* & Vochysiaceae & 70 & $4.4 \pm 3.6$ & 15 & - & - & - \\
\hline Total & & 553 & & 16 & & & \\
\hline
\end{tabular}

${ }^{*}$ Species inoculated with mistletoe seeds

Table 3. Tree abundance, height and prevalence of three mistletoe species of Psittacanthus (Loranthaceae) in a 4.5 ha ( $150 \mathrm{~m} \times 300 \mathrm{~m}$ ) plot of savanna near Alter do Chão, Pará, Brazil (data from dataset 2). Data only include tree species parasitized with mistletoes in the dataset 1.

\begin{tabular}{|c|c|c|c|c|c|}
\hline Tree species & Total abundance & Height $(\mathrm{m})( \pm \mathrm{SD})$ & $\begin{array}{c}\text { P. biternatus } \\
\text { Prevalence (\%) }\end{array}$ & $\begin{array}{l}\text { P. eucalyptifolius } \\
\text { Prevalence (\%) }\end{array}$ & $\begin{array}{l}\text { P. plagiophyllus } \\
\text { Prevalence(\%) }\end{array}$ \\
\hline Anacardium occidentale & 122 & $3,3 \pm 1,6$ & - & - & $48(39)$ \\
\hline Byrsonima coccolobifolia & 468 & $2,3 \pm 1,7$ & $15(3.2)$ & - & - \\
\hline Byrsonima crassifolia & 1475 & $2,3 \pm 1,2$ & $6(0.4)$ & - & - \\
\hline Pouteria ramiflora & 825 & $3,4 \pm 1,7$ & $14(1.7)$ & - & - \\
\hline Vatairea macrocarpa & 1212 & $2,4 \pm 1,3$ & - & $4.5(55)$ & - \\
\hline Total & 4102 & & $35(1.2)$ & & \\
\hline
\end{tabular}


lyptifolius were found in $6 \%$ of the tree individuals tagged in dataset 2, and only $3.4 \%$ of the individuals of $V$. macrocarpa received at least one seed. Seed deposition of P. eucalyptifolius was not proportional to relative tree abundance in dataset $2\left(x^{2}=33.4, \mathrm{df}=4, \mathrm{P}<0.001\right.$; Fig. $\left.2 \mathrm{a}\right)$, including a lower than expected proportion of $V$. macrocarpa receiving their seeds.

Seeds of $P$. eucalyptifolius inoculated experimentally germinate a few days after being released from the pericarp. As in P. biternatus, seed survivorship was also widespread but markedly different across the nine tree species (Fig. 2b). After one year, seeds of P. eucalyptifolius inoculated on the nine tree species had only established on $V$. macrocarpa (Fig. 2c).

\section{Psittacanthus plagiophyllus}

This species was found uniquely as a parasite of the cashew tree, Anacardium occidentale. It is one of the trees with lower relative abundance at the study site and in the region (R. Fadini, pers. obs.), but was heavily parasitized by P. plagiophyllus (dataset 2, Tab. 3).

Seeds of $P$. plagiophyllus were produced abundantly and arrived at $13.2 \%$ of the tagged trees, and in $24.6 \%$ of $A$. occidentale individuals in dataset 2 . Seed deposition was not proportional to relative tree abundance in P. plagiophyllus $\left(x^{2}=89.9, \mathrm{df}=4, \mathrm{P}<0.001\right.$; Fig. 3a), and occurred more than expected in A. occidentale. However, this test rendered a non-significant result when I removed the infected cashew trees from the analysis.

Although seeds of P. plagiophyllus experimentally inoculated could survive up to seven months on $V$. macrocarpa ( $10 \%$ of the planted seeds), they only germinate when in contact with A. occidentale (Fig. 3b), even though it also takes at least one month to occur. Likewise, establishment is only possible in A. occidentale, where $37 \%$ of the planted seeds have been established after seven months (Fig. 3c).

\section{Interspecific comparisons: seed deposition, seed survivorship and seedling establishment}

Sixty-seven individuals ( $8.3 \%$ of the 801 tree individuals that received seeds) had seeds of both P. eucalyptifolius and P. plagiophyllus; five individuals (0.6\%) of P. biternatus and P. plagiophyllus; 2 individuals $(0.25 \%)$ of $P$. biternatus and $P$. eucalyptifolius, and only one individual ( $0.1 \%)$ had all three mistletoe seeds. Therefore, patterns of seed deposition among mistletoe species were not spatially correlated, since there was low overlap among individual trees receiving more than one mistletoe species. On the other hand, a similar proportion of each tree species received seeds of both P. eucalyptifolius and P. plagiophyllus (Monte Carlo test: $\mathrm{r}=0.85, \mathrm{P}=0.03$, after 100 randomizations), but not of P. plagiophyllus and P. biternatus $(\mathrm{r}=0.15, \mathrm{P}=0.46)$, or $P$. eucalyptifolius and P. biternatus $(\mathrm{r}=0.55, \mathrm{P}=0.15)$.
The proportion of surviving seeds in the seed inoculation experiment was, on average, 1.8 times higher on P. eucalyptifolius that on P. biternatus $(0.26 \pm 0.37$ vs. $0.14 \pm 0.25, \mathrm{~F}_{1,119}=5.76, \mathrm{P}=0.02$ ), differences between the two mistletoes depend greatly on the tree species considered (tree $\mathrm{x}$ mistletoe interaction: $\mathrm{F}_{8,119}=4.64, \mathrm{P}$ $<0.001)$. P. biternatus performed better than P. eucalyptifolius in five species (Fig. 1b), while Psittacanthus eucalyptifolius performed better than P. biternatus in four tree species (Fig. 2b). Additionally, there was a negative but not significant correlation between the proportion of seed survivorship of $P$. eucalyptifolius and P. biternatus (Spearman rho $=-0.57, \mathrm{P}=0.1$ ). Comparisons between P. plagiophyllus the other two Psittacanthus species were not possible due to differences in environmental conditions during the time of seed exposure. However, it becomes evident from the results that P. plagiophyllus is highly specialized on A. occidentale.

\section{Discussion}

There was no overlap among trees used as hosts by three Psittacanthus species occurring in an Amazonian savanna patch. Psittacanthus biternatus was a generalist, parasitizing some of the most common tree species, P. eucalyptifolius occurred only on Vatairea macrocarpa, while P. plagiophyllus occurred on only one of the less abundant species, the cashew tree Anacardium occidentale. This contradicts the current ideas suggesting that when tree species have low relative abundance, they are unable to support specialized parasites (Norton \& Carpenter 1998). Furthermore, this study highlights the importance of mistletoe-host compatibility as an important determinant of host use and the patterns of infection prevalence in mistletoes.

\section{Infection patterns: tree abundance}

Mistletoe infection prevalence was only partially related to relative tree abundance in one of the three mistletoe species. As predicted, P. biternatus infected the commonest tree species, $B$. crassifolia, and its congener, $B$. coccolobifolia (together performing on $28.2 \%$ of tree individuals). On the other hand, mistletoes did not infect the second and third most common trees (S. convallariodora and Q. grandiflora, Vochysiaceae; $23.9 \%$ of individuals) on the sample plots. This is interesting because members of this family are the main host trees for another Psittacanthus species (P. robustus) in Central Brazilian Cerrado, and there, relative abundance seems to influence mistletoe specificity (Monteiro et al. 1992). The other tree species infected by $P$. biternatus was Pouteria ramiflora. Despite being the fourth most common tree at this study site, this species corresponds to only $8.5 \%$ of tree individuals. In sum, I have not found evidence to support the hypothesis that tree abundance is the main factor leading to infection patterns. 

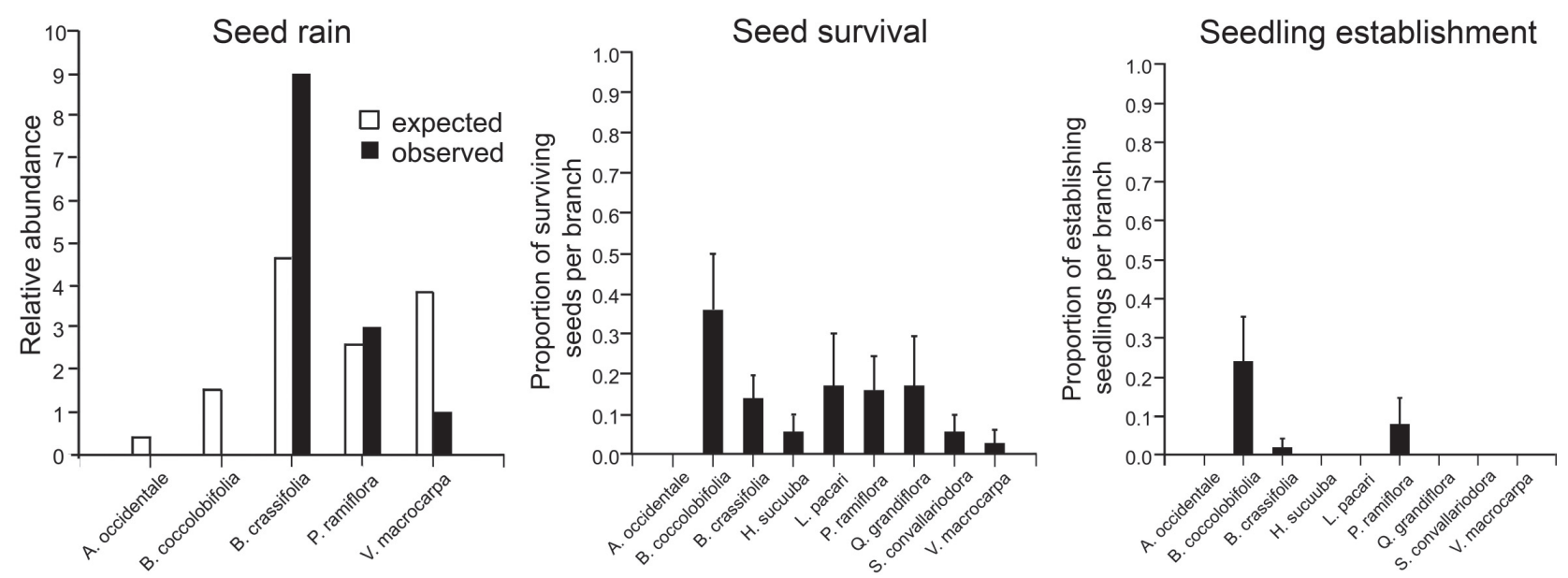

Figure 1. From left to right: a) seed deposition, b) seed germination and c) seedling establishment of Psittacanthus biternatus on potential host trees in Alter do Chão, PA, Brazil. In a) filled bars represent the observed number of trees of potential host species that received at least one mistletoe seed, while open bars represent the expected number of trees receiving mistletoe seeds based on their relative abundance. In b) bars represent the mean number of seeds remaining one year after inoculation plus SE. In c) bars represent the mean number of seedlings establishing one year after inoculation plus SE.
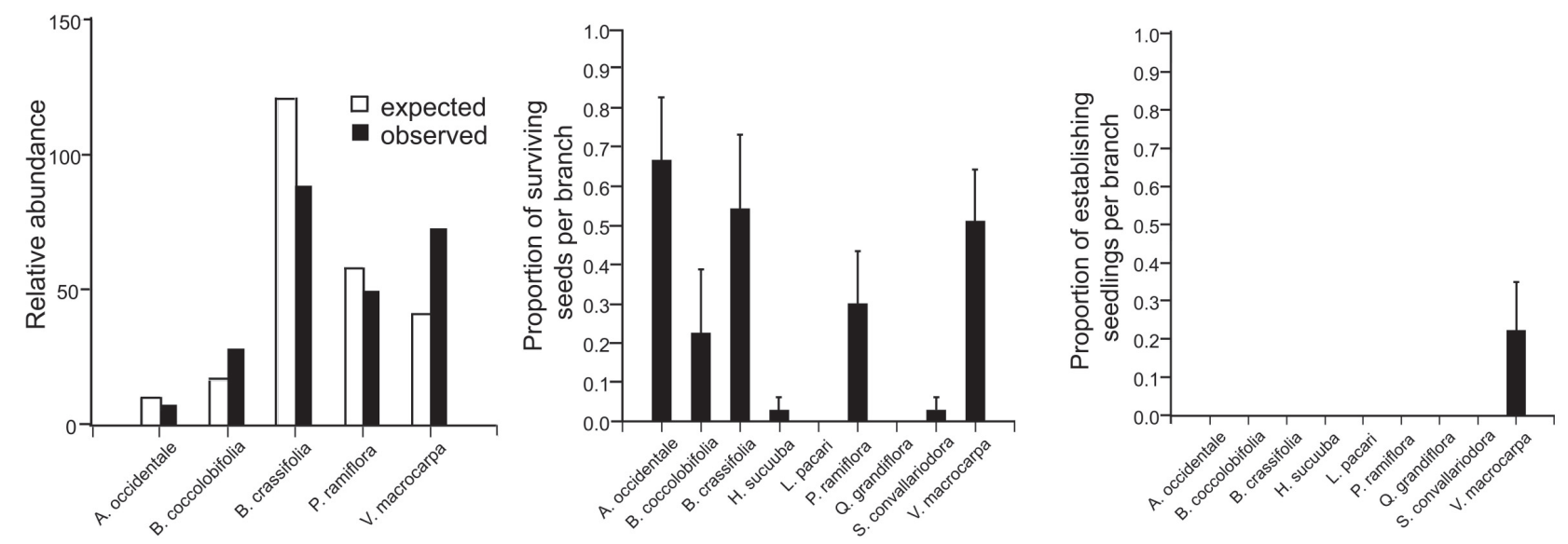

Figure 2. Seed deposition, seed germination and seedling establishment of Psittacanthus eucalyptifolius on potential host trees in Alter do Chão, PA, Brazil. In b) and c): see Fig. 1 for graph specifications.

In a study of plants infected by Struthanthus polyanthus (Loranthaceae), Arruda et al. (2006) suggest that other factors, in addition to abundance, were also responsible for observed patterns of infection such as the rough bark of the species, and the incapacity to accumulate silica on its tissues, that act as a physical barrier to mistletoe haustorium penetration on trees. A crucial next step in this research would be to investigate the role of these tree traits explaining patterns of mistletoe infection and mistletoe-host association.

Although P. biternatus was the most generalist mistletoe species, it was not totally unspecific with respect to host trees, being more prevalent than expected on $B$. coccolobifolia and on P. ramiflora, the two least common hosts. It is evident that other factors, in addition to host abundance, are necessary to explain mistletoe infection prevalence for this species. A similar pattern has been shown for other mistletoe species, where this is probably related to disproportionate seed rain on some host trees (López De Buen \& Ornelas 1999; Aukema \& Martinez Del Rio 2002) and/or to mistletoe-host compatibility (López De Buen \& Ornelas 2002).

Another common predicted pattern in mistletoes is the size-occupancy relationship wherein larger trees are disproportionately infected (Overton 1994). Roxburgh \& Nicolson (2005) had extrapolated this to between tree species and found a significant effect of tree height on mistletoe prevalence for one of the two mistletoe species they studied. I found that the tallest trees in the study site (Salvertia convallariaeodora and Sclerolobium paniculatum) were not infected by mistletoes, and therefore, that host size seems not to influence mistletoe infection patterns. 

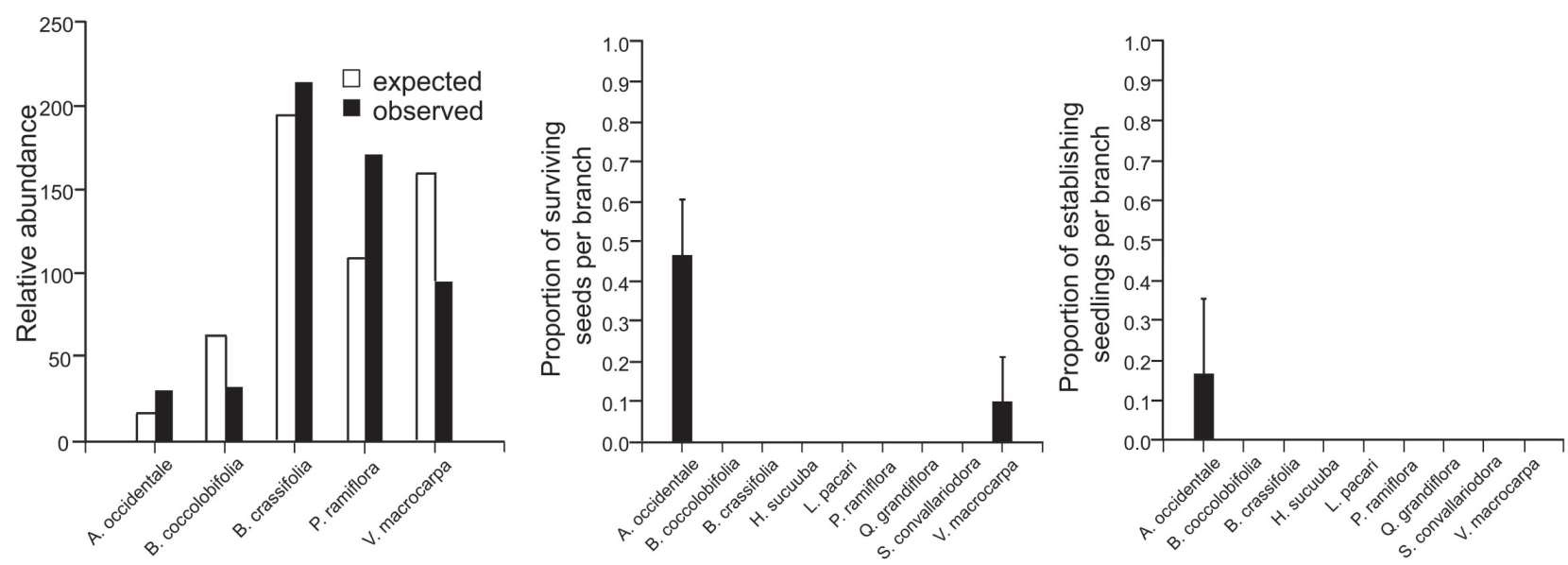

Figure 3. Seed deposition, seed germination and seedling establishment of Psittacanthus plagiophyllus on potential host trees in Alter do Chão, PA, Brazil. In b) and c): see Fig. 1 for graph specifications, except that the total period of the experiment is 7 months.

\section{Seed- rain patterns}

Few tree individuals shared seeds of different mistletoe species, but the proportion of each tree individual of each species receiving seeds was highly correlated between $P$. eucalyptifolius and P. plagiophyllus. Despite the low number of seeds of $P$. biternatus, these results suggest that seed dropping locations of seed dispersers after consuming mistletoe fruits of different species were not correlated, indicating absence of spatial autocorrelation or that they were not grouped by spatial proximity, which may arise from distinct positions of mistletoe species within the sample plot. On the other hand, there was a high correlation between the proportion of host trees receiving seeds of either P. eucalyptifolius or P. plagiophyllus. As these two mistletoe species do not overlap fruiting periods, they could be dispersed by the same birds. Furthermore, because they parasitize different tree species, seed dispersers should play a small role in determining their tree specificity. A similar approach has been suggested for two Australian mistletoes (Yan 1993), but the present study is the first to provide empirical evidence of this mechanism (or the lack of it).

A disproportionate seed rain on tree species occurred for all mistletoes. This provides indirect evidence that birds visit some tree species more often than expected from their abundance. Several other studies have made observations of bird dispersers visiting some host trees more frequently than others (López De Buen \& Ornelas 1999; Roxburgh \& Nicolson 2005). In this study, I also considered other non-host trees in order to explain specialization. Only $P$. biternatus had a disproportionate seed rain onto one of its host trees. Nevertheless, seed rain does not fully predict the current patterns of mistletoe infection prevalence, and therefore, mistletoe-host compatibility may be a major factor influencing infection (e.g. López de Buen \& Ornelas, 2002). For P. eucalyptifolius, I found a higher proportion of B. crassifolia receiving mistletoe seeds than expected, but its unique host $V$. macrocarpa had a lower proportion of individuals receiving seeds than predicted. Finally, a much greater than expected proportion of $P$. plagiophyllus seeds were found on A. occidentale and P. ramiflora. However, this result disappeared when I removed the infected trees of its own host species (A. occidentale) from the analysis. In summary, except for $P$. biternatus, seed rain patterns were not related to trees selected as hosts by mistletoe species, being more common on non-host than on host trees. These patterns can be better understood if we take an approach that considers the positions of mistletoe infections, the relative abundance of tree species, and the movement of bird dispersers within the subplots. Ideally, there should be a combination of post-foraging observations of potential bird dispersers and a survey of mistletoe seeds for all tree species available (e.g. Medel et al. 2004).

\section{Mistletoe-host compatibility}

Seedling establishment of mistletoes on different tree species provided unequivocal evidence that mistletoe-host compatibility is the main factor driving the observed pattern of mistletoe specialization in Psittacanthus species. Additionally, the patterns of mistletoe infection prevalence on P. biternatus nicely match the results of the field experiment, suggesting that the activity of frugivorous birds is not required to explain the patterns found. The seed inoculation experiment revealed that: mistletoe seedlings could survive for one year or more without establishing on non-host trees (Lamont 1983); congener mistletoe species living in sympatry may require very different host stimuli and/or resources to establish on unrelated host species (Yan \& Reid 1995); and some mistletoe species (P. plagiophyllus) may not even be able to germinate on the wrong tree species.

Several studies have found that mistletoes soon germinate after being released from the exocarp (Lamont 1983; 
Yan 1993). In this study, P. biternatus germinated a few hours after being released, while P. eucalyptifolius germinated in a few weeks. Nevertheless, mistletoe seedlings are often shortlived, frequently dying within one year or less (Yan \& Reid 1995, Roxburgh \& Nicolson 2005). A large proportion of seedlings of $P$. eucalyptifolius survived within one year after experimental seed inoculation on some non-host trees (e.g. $67 \%$ on A. occidentale, and $54 \%$ on B. crassifolia, see López de Buen \& Ornelas 2002 for a similar pattern on host trees). Likewise, most seedlings of $P$. biternatus had also survived on potential host trees in this period. Nonetheless, these seedlings all died by two years after inoculation (personal observation); some of them had, though, produced fissures on the bark of hosts and non-host trees species during the cotyledon phase. This suggests that most seeds do not recognize the host but simply germinate and then suffer delayed mortality because of host incompatibility that occurs at the stage when the haustorium penetrates the host bark (Yan 1993); or that mistletoes may not establish successfully unless specific host attractive physiological conditions are met.

Unlike seed germination, successful seedling establishment frequently depends on the tree species where the mistletoe seed is deposited (Hoffmann et al. 1986; Yan 1993). Calder (1983) suggested that mistletoe penetration of host tissues depends primarily on host resistance, and on mistletoe infectivity. Therefore, trees with thicker bark may resist mistletoe penetration, while a mistletoe that penetrates should also produce sufficient enzymes to invade the xylem (Yan 1993b). In this study, all mistletoes were unable to establish on four of the nine host species; three have thick bark (H. sucuuba, Q. grandiflora, and $S$. convallariodora), and one has exfoliating bark (L. pacari). However, it is unlikely that bark resistance was the main barrier to mistletoe penetration, perhaps because the branch thickness selected for experiments was too thin to prevent haustorium development (Sargent 1995). Among the five tree species selected as hosts by mistletoe species, three also have thick bark (P. ramiflora, A. occidentale, $B$. coccolobifolia), and therefore, it is more likely that a specific chemical recognition between mistletoe and host is required to allow haustorium penetration into the xylem, instead of a simple physical barrier of the bark (but see Yan 1993b for a different conclusion). Furthermore, the presence of silicon and the association with ants in some host species such as L. pacari and Q. grandiflora should also be evaluated as potential factors precluding the penetration of mistletoe haustorium on host tissues.

The strongest evidence suggesting that mistletoes require specific stimuli to grow on a subset of tree species is exemplified by the relationship between P. plagiophyllus and $A$. occidentale. Seeds or seedlings of Psittacanthus plagiophyllus were not observed on different host trees, neither in sample plots nor outside them. Likewise, none of the 240 seeds inoculated on non-host trees germinated (presented cotyledon expansion). To the best of my knowledge there are no studies documenting this pattern for mistletoes.

\section{Acknowledgements}

This research was supported by the Conselho Nacional de Desenvolvimento Científico e Tecnológico (CNPq), Brasil, (Edital Universal: project no. 479130/2006-0), and CAPES (doctoral fellowship). I thank Carlos Reif for mistletoe identification. Danielly Miléo, Davi Corrêa, Deliane Penha, Rúbia Reis, Wellington Ferreira, and Geniandreson Ferreira helped during the field work. I am indebted with the families of Laudelino Vasconcelos and Raimundo Castelo for assistance and friendship during all the period of data collection. Renato Cintra, Scott Stark, Flávia Costa, Marina Anciães, Antônio Webber and Kléber Del Claro provided valuable suggestions on earlier versions.

\section{References}

Arruda, R.; Carvalho, L.N. \& Del-Claro, K. 2006. Host specificity of a Brazilian mistletoe Struthanthus aff. polyanthus (Loranthaceae), in cerrado tropical savanna. Flora 201: 127-134.

Aukema, J.E. \& Martinez Del Rio, C.M. 2002. Variation in mistletoe seed deposition: effects of intra- and interspecific host characteristics. Ecography 25: 139-144.

Barlow, B.A. \& Wiens, D. 1977. Host-parasite resemblance in Australian mistletoes: case for cryptic mimicry. Evolution 31: 69-84.

Calder, D.M. 1983. Mistletoe in focus: an introduction. Pp. 1-17. In: Calder, D.M. \& Bernhardt, P. (Ed.). The biology of mistletoes. Sydney, Academic Press.

Fadini, R.F; Gonçalves, D.C.M. \& Reis, R.P.F. 2009. Consistency in seeddeposition patterns and the distribution of mistletoes among its host trees in an Amazonian savanna. Australian Journal of Botany 57: 640-646.

Hoffmann, A.J.; Fuenes, E.R.; Cortés, I.; Liberona, F. \& Costa, V. 1986. Tristerix tetrandrus (Loranthaceae) and its host plants in the Chilean matorral: patterns and mechanisms. Oecologia 69: 202-206.

Lamont, B.B. 1983. Germination of mistletoes. Pp. 129-141. In: Calder, M. \& Bernhardt, P. (Ed.). The biology of mistletoes. Sydney, Academic Press.

López De Buen, L. \& Ornelas, J.F. 1999. Frugivorous birds, host selection and the mistletoe Psittacanthus schiedeanus, in central Veracruz, Mexico. Journal of Tropical Ecology 15: 329-340.

López De Buen, L. \& Ornelas, J.F. 2002. Host compatibility of the cloud forest mistletoe Psittacanthus schiedeanus (Loranthaceae) in central Veracruz, Mexico. American Journal of Botany 89: 95-102.

Marshall, J.D. \& Ehleringer, J.R. 1990. Are xylem-tapping mistletoes partially heterotrophic? Oecologia 84: 244-248.

Martin, T.G.; Wintle, B.A.; Rhodes, J.R.; Kuhnert, P.M.; Field, S.A.; Low-Choy, S.J.; Tyre, A.J. \& Possingham, H.P. 2005. Zero tolerance ecology: improving ecological inference by modelling the source of zero observations. Ecology Letters 8: 1235-1246.

May, D.S. 1971. Role of populational differentiation in experimental infection of Prosopis by Phoradendron. American Journal of Botany 58: $921-\&$.

Medel, R.; Vergara, E.; Silva, A. \& Kalin-Arroyo, M. 2004. Effects of vector behavior and host resistance on mistletoe aggregation. Ecology 85: 120-126.

Miranda, I.S. 1993. Estrutura do estrato arbóreo do cerrado amazônico em Alter-do-Chão, Pará, Brasil. Revista Brasileira de Botânica 16: 143-150.

Monteiro, R.F.; Martins, R.P. \& Yamamoto, K. 1992. Host specificity and seed dispersal of Psittacanthus robustus (Loranthaceae) in south-east Brazil. Journal of Tropical Ecology 8: 307-314. 
Norton, D.A. \& Carpenter, M.A. 1998. Mistletoes as parasites: host specificity and speciation. Trends in Ecology \& Evolution 13: 101-105. Norton, D.A. \& De Lange, P.J. 1999. Host specificity in parasitic mistletoes (Loranthaceae) in New Zealand. Functional Ecology 13: 552-559.

Overton, J.M. 1994. Dispersal and infection in mistletoe metapopulations. Journal of Ecology 82: 711-723.

Roxburgh, L. \& Nicolson, S.W. 2005. Patterns of host use in two African mistletoes: the importance of mistletoe-host compatibility and avian disperser behavior. Functional Ecology 19: 865-873.

Sanaiotti, T.M. \& Magnusson, W.E. 1995. Effects of annual fires on the production of fleshy fruits eaten by birds in a Brazilian Amazonian savanna. Journal of Tropical Ecology 11: 53-65.
Sargent, S. 1995. Seed fate in a tropical mistletoe: the importance of host twig size. Functional Ecology 9: 197-204.

Yan, Z. 1993. Germination and seed development of two mistletoes, Amyema preissii and Lysiana exocarpii: host specificity and mistletoehost compatibility. Australian Journal of Ecology 18: 419-429.

Yan, Z. 1993. Resistance to haustorial development of two mistletoes, Amyema preissii (Miq.) tieghem and Lysiana exocarpi (Behr.) tieghem ssp. exocarpi (Loranthaceae), on host and nonhost species. International Journal of Plant Sciences 154: 386-394.

Yan, Z.G. \& Reid, N. 1995. Mistletoe (Amyema miquelii and A. pendulum) seedling establishment on eucalypt hosts in eastern Australia. Journal of Applied Ecology 32: 778-784. 